\title{
Guido Saba, Bibliographie des écrivains français. Théophile de Viau
}

\section{Laura Rescia}

\section{Q OpenEdition}

1 Journals

\section{Edizione digitale}

URL: http://journals.openedition.org/studifrancesi/8895

DOI: 10.4000/studifrancesi.8895

ISSN: 2421-5856

\section{Editore}

Rosenberg \& Sellier

\section{Edizione cartacea}

Data di pubblicazione: 1 octobre 2008

Paginazione: 449

ISSN: 0039-2944

\section{Notizia bibliografica digitale}

Laura Rescia, "Guido Saba, Bibliographie des écrivains français. Théophile de Viau», Studi Francesi [Online], 155 (LII | II) | 2008, online dal 30 novembre 2015, consultato il 11 janvier 2021. URL: http:// journals.openedition.org/studifrancesi/8895 ; DOI: https://doi.org/10.4000/studifrancesi.8895

Questo documento è stato generato automaticamente il 11 janvier 2021.

\section{(c) (i) (9)}

Studi Francesi è distribuita con Licenza Creative Commons Attribuzione - Non commerciale - Non opere derivate 4.0 Internazionale. 


\title{
Guido Saba, Bibliographie des écrivains français. Théophile de Viau
}

\author{
Laura Rescia
}

\section{NOTIZIA}

GUIDO SABA, Bibliographie des écrivains français. Théophile de Viau, Memini, 2007, pp. 314.

1 Segnaliamo la pubblicazione del ventinovesimo volume di una serie connotata da un buon grado di esaustività e attualità (l'edizione in CD Rom dovrebbe essere aggiornata ogni quinquennio), nonché dalla facilità nell'uso, caratteristica che la renderà accessibile anche ai non specialisti: le opere critiche ritenute fondamentali sono segnalate dal logo lunettes, ogni voce della bibliografia critica è corredata dalle sue parole chiave, gli indici sono numerosi. Il volume dedicato a Théophile, con le sue 1304 voci, riprende la struttura della collana, ed è particolarmente ricco nella parte relativa alle edizioni antiche: la bibliografia di F.Lachèvre, risalente al 1909, è stata rivista, emendata e completata minuziosamente. La sezione tematica distingue, oltre agli studi biografici e a quelli generali, i lavori dedicati alla fortuna dell'opera e del personaggio (compresi i testi polemici coevi, precedenti e successivi alla scomparsa di Théophile), per poi raggruppare le voci in base ai generi letterari, a cui si aggiungono due sezioni dedicate al libertinaggio e alle poesie musicate (partiture e registrazioni). Nei Desiderata finali, l'autore auspica un rinnovamento degli studi biografici, in particolare per quanto riguarda la formazione di Théophile e i suoi rapporti con il mondo teatrale, nonché un futuro inserimento della sua opera nei programmi dell'aggrégation. 